\title{
An omnichannel approach to retailing: demystifying and identifying the factors influencing an omnichannel experience
}

\section{Abstract}

The purpose of this research is to identify the factors that influence an omnichannel experience. Omnichannel is an emerging approach to retailing that responds to the changing nature of how customers shop in alternation between online and offline shops, and the increasing use of digital devices (e.g. smartphones and tablets), as a consequence retailers are focusing and establishing a seamless integrated approach to their services. Omnichannel is now a hot topic in retailing but there is a lack of empirical studies into the factors that influence an omnichannel experience. Using a mixed methods approach, we propose and empirically test a conceptual model that identifies four factors influencing an omnichannel experience: brand familiarity; customisation; perceived value, and technology readiness. We conceptualise omnichannel to include three key channels; in-store, online and mobile. 246 questionnaires were collected and analysed using PLS-SEM and 11 interviews with marketing/omnichannel professionals. Our results indicate that brand familiarity has a strong influence on omnichannel (in-store, online and mobile) while perceived value has a negative impact on mobile experience. Our results show that retailers need to consider multiple factors, such as brand familiarity customisation, perceived value and technology readiness as influencing factors of an omnichannel experience, and plan the use of multiple touchpoints simultaneously to enhance their overall customer's experience. Although this study demonstrates the significant factors influencing an omnichannel experience, questions remain regarding the exact use of each touchpoint 
by customers and the extent of overlap between the touchpoints. Our research attempts to address the lack of academic research on what factors influence an omnichannel experience.

\section{Introduction}

In recent years there has been a notable increase in customers shopping online rather than in physical shops, it can be seen that online shopping is now dominating retail growth (Hsiao, Yen and Li 2012). This has resulted in new types of retail channels and touchpoints that influence customers' behaviour. Shopping on smartphones and tablets has achieved significant growth, in 2017 34\% of all e-retail sales were made on a mobile device, this is predicted to grow to 54\% in 2021 (Statista, 2019). Retail research (2018), report that during 2017 online and mobile channel to market represented over $£ 77 \mathrm{bn}$ of transactions, which was an increase of more than $11.5 \%$ over 2016. Smartphones have revolutionised shopping, with the use of mobile apps, location targeted offers and scan-and-go technologies (Grewal, Roggeveen and Nordfält 2017).

In response to this growth online and subsequent change of customer behaviour, the concept of omnichannel management started from a practitioners' perspective (Rigby, 2011). Omnichannel is as a new method to enhance customers' shopping experience and overcome any shortcomings of a multichannel approach to retailing. Omnichannel is defined as "the synergetic management of the numerous available channels and customer touchpoints, in such a way that the customer experience across channels and the performance over channels is optimized" (Verhoef, Kannan and Inman 2015, 176). An omnichannel approach to retailing takes a broader 
perspective on channel integration and how this affects customers' choice and purchase behaviours.

Since customers expect a seamless, consistent experience across all channels, having a multichannel presence and strategy is, however, not enough. The omnichannel approach integrates customer experience and focus on all customer interactions with an organisation through a customer's lens (Yrjölä, Spence and Saarijärvi 2018). The omnichannel approach also places greater emphasis on the integration between the digital and traditional channels (Beck and Rygl, 2015; PicotCoupey, Huré and Piveteau 2016).

There is a scarcity of research examining an omnichannel approach to retailing and how this affects the customer experience (Verhoef, Kannan and Inman 2015; Ye, Lau and Teo 2018). By identifying the factors that influence omnichannel adoption by customers, we can address the shortcoming in the literature by proposing and testing a hypothesised model for omnichannel experience in retailing from the perspective of customers. We contribute to the empirical omnichannel literature by providing further insight into the impact of four key factors influencing an omnichannel experience. We investigate the customer's experience across online, in-store and mobile channels from a customer's viewpoint on how these channels are influenced in a retail shopping environment.

\section{From multichannel to omnichannel}

Given the changing shopper patterns, multichannel shopping is where customers use multiple channels such as online, or mobile devices to purchase products or services (Zhang et al 2010). The extant literature illustrates that a retailer's multichannel approach could enhance customers' satisfaction and increase loyalty 
(Wallace, Giese and Johnson 2004). Retailers that utilise a multichannel approach often generate greater sales and profit in comparison to a single-channel approach (Huang, Lu and Ba 2016; Zhang et al 2010;). Where customers shop across multiple product categories there is a greater propensity to make purchases via multichannel and more likely to migrate to a new channel. However, that channel might deliver a different experience for the customer (Kumar and Venkatesan, 2005).

Multichannel retailing considers channels such as online and in-store, but often these retail channels are managed and accounted for separately (Neslin and Shankar 2009). It should be noted that there is a distinction between multiple channels and channel integration (Friedman and Furey, 2003). Neslin and Shankar (2009) posit that the multichannel research hitherto has focussed on the growth of online channels, not the integration of the channels. Retailers have developed and managed the channels separately with limited integration (Saghiri et al 2017). Omnichannel includes integrating cross-channel objectives with the lens being on the customer and brand rather than a retail channel or sales focus (Verhoef, Kannan and Inman2015). The focal point of omnichannel management is integrating the channels, thus providing customers with a seamless retail experience (Verhoef Kannan and Inman 2015; Yrjölä, Spence and Saarijärvi 2018). Although channel integration has become the cornerstone of marketing strategies, putting such an approach into practice remains a major challenge for retailers (Melero, Sese and Verhoef 2016).

Different retail channels are now interchangeable as customers are using multiple channels in a seamless way (Verhoef, Kannan and Inman 2015), as it's simpler for them to move between channels at any point. This has led to academic research to highlight the importance of considering customer experience and ensuring 
a consistent method to drive a more positive experience (Melis et al 2015). Gallino and Moreno (2014) argue that customers often view the organisation as one entity, regardless of how many channels they use, hence retailers should adopt a consistent approach. Despite the number of channels or the methods of their integration, retailers should keep sight of customer experience and seek to integrate the customer experience across all channels to reduce conflicts and difficulties in integrating their processes (Kim, Park and Pookulangara 2005). Integrating this experience across all channels allows for a consistent and seamless customer experience (Steinfield and Harry Bouwman 2002), which empowers the customer with more self-control to shop (Zhang et al2018). This study investigates the customer's experience across different channels to identify factors that influence the omnichannel experience.

\section{Omnichannel approach to retailing: definition and constituent dimensions}

Following interviews with a range of marketing professionals, including a leading omnichannel agency in London, the three main channels identified are online, mobile and in-store. Lemon and Verhoef (2016) argue that there are more touchpoints with customers, including direct marketing, telephone and traditional media, and understanding the customer journey is of importance. Also, understanding the elements of customer experience touchpoints highlighted by Stein and Ramaseshan (2016). Their research highlighted the effect of customer-to-customer and employeeto-customer interactions as important touch points that could affect an experience within a channel. We recognise there are multiple touchpoints that can affect a customer's experience. For this research, online, mobile and in-store are the three principal channels investigated. 
Mobile technology has seen dramatic growth in customer usage, which has had a disruptive effect on online retailing (Einav et al 2014). As an effect of this growth "more e-commerce websites are providing mobile shopping services that enable their consumers to access their products and services through an additional online channel" (Huang et al 2016, 265). The flexibility, ease of use and mobility motivate customers to better understand mobile shopping and improve ease of use perception (Hubert et al 2017). Both Einav et al (2014) and Huang, Lu and Bal (2016) identify retailer's initiatives to adapt their e-commerce to m-commerce. With the need to have a competitive multichannel approach (Zhang et al 2010), retailers have attempted to take advantage of mobile capabilities, such as convenience, accessibility, security and optimisation (Tseng and Yazdanifard, 2015), to create a positive online experience (Huang Lu and Ba 2016; Pantano and Priporas 2016).

Research undertaken by IBM, globally, found that $78 \%$ of respondents identified themselves as digital device adopters, with customers increasingly shopping via multichannels and using mobile devices (Berman and Kesterson-Townes, 2012). Several retailers are reporting that $70-80 \%$ of website browsing occurs through mobile devices, such as smart phones and tablets. Online retail sales in 2016 increased by $16.7 \%$, from the previous year, with a total ecommerce spend online of $£ 182 b n$ in Europe. The major growth of online sales in retail is underpinned by the use of mobile devices. In the UK $35.6 \%$ of mobile sales occurred and it is expected that $89.2 \%$ of mobile purchases online will occur in Europe during 2015-2017 (Anon 2018). The technological advances in mobile devices enable customers to instantly access and download information, make purchases online and engage in online services such as click and collect (Rose, Hair and Clark 2011). 
We contend that omnichannel is an integral part of the customer experience because it is concerned with all customer interactions with a retailer from a holistic perspective. When a retailer adopts an omnichannel approach they can integrate the customer experience both online and offline through each of the touchpoints with their customers.

Table 1 provides an overview of the key literature surrounding omnichannel and multichannel retailing. The analysis of the literature shows that there is a lack of academic research into our understanding about the factors that influence an omnichannel experience. The focal point of most of the extant literature to date has been on the multichannel approach to retailing or from a channel management, supply chain focus, this is identified by Galipoglu et al (2018).

The research available identifies the challenges retailers face when adopting channel integration and forming an omnichannel approach. However, the omnichannel research is predominantly conceptual in nature and highlights the lack of research into what drives an omnichannel experience (Ye, Lau and Teo 2018). By integrating channels, retailers need to deliver a consistent, seamless experience across all touchpoints (Picot-Coupey, Huré and Piveteau 2016). The latest, limited omnichannel literature focuses on distribution and supply chain related issues rather than the customer's experience and what drives an omnichannel experience (Saghiri, et al 2017; Ye, Lau and Teo 2018; Cao and Li. 2018). There are limited empirical studies within the omnichannel literature and none specifically that investigate the factors that influence the omnichannel experience. 
Table 1: Overview of Omnichannel literature

\begin{tabular}{|c|c|c|c|}
\hline Author(s) & Context & $\begin{array}{l}\text { Type of } \\
\text { study }\end{array}$ & Relationship to Omnichannel \\
\hline $\begin{array}{l}\text { Barwitz \& Maas } \\
(2018)\end{array}$ & Omnichannel & Empirical & $\begin{array}{l}\text { Identifies an understanding of what drives customers' interaction choices along the customer journey, motives for a customer } \\
\text { journey and channel choice and investigates the value-in-use customers seek in interactions with a company. }\end{array}$ \\
\hline Cao \& Li (2018) & $\begin{array}{l}\text { Multichannel } \\
\text { Omnichannel }\end{array}$ & Conceptual & $\begin{array}{l}\text { Investigation into cross-channel integration in US retail companies indicate that retailers' IT capabilities and private-label } \\
\text { provision drive their cross-channel integration. }\end{array}$ \\
\hline $\begin{array}{l}\text { Galipoglu, et al } \\
(2018)\end{array}$ & Omnichannel & Conceptual & $\begin{array}{l}\text { From undertaking a comprehensive a literature review on omnichannel and logistics/supply chain this study highlights the lack } \\
\text { of research in this area. }\end{array}$ \\
\hline $\begin{array}{l}\text { Yrjölä, et al } \\
(2018)\end{array}$ & Omnichannel & Conceptual & Identifies how multi, cross and omnichannel CVPs differ in terms of how they create value to customers. \\
\hline Ye, et al (2018) & Omnichannel & Empirical & $\begin{array}{l}\text { Highlights the lack of research on drivers of an omnichannel experience, adds to the literature to identify drivers from a } \\
\text { marketing, logistics and supply chain perspective. Customer service and product innovativeness highlighted as part of an } \\
\text { omnichannel success but many barriers such as IT, resources and supply chain not being centralised can cause problems. }\end{array}$ \\
\hline $\begin{array}{l}\text { Yrjölä, et al } \\
\text { 2018). }\end{array}$ & Omnichannel & Conceptual & $\begin{array}{l}\text { The omnichannel environment enables the retailer to facilitate customers' value by creating processes throughout their } \\
\text { consumption journey. The authors propose } 5 \text { propositions to facilitate the decision-making process and adding value to the } \\
\text { customers journey. Customer satisfaction and trust are influences by this empowerment. }\end{array}$ \\
\hline $\begin{array}{l}\text { Zhang et al } \\
(2018)\end{array}$ & Omnichannel & Empirical & $\begin{array}{l}\text { Results find that consumer perceptions of channel integration have a positive relationship with consume empowerment. In an } \\
\text { omnichannel environment, consumers are empowered with more self-control to shop. }\end{array}$ \\
\hline $\begin{array}{l}\text { Ailawadi \& } \\
\text { Farris (2017) }\end{array}$ & $\begin{array}{l}\text { Multichannel } \\
\text { Omnichannel }\end{array}$ & Conceptual & $\begin{array}{l}\text { Identifies the growing capabilities and importance of mobile that has accelerated implementation of omnichannel strategies by } \\
\text { retailers. There is an increased pressure on suppliers to adopt and adapt by integrating across their channels. }\end{array}$ \\
\hline $\begin{array}{l}\text { Grewal et al } \\
(2017)\end{array}$ & $\begin{array}{l}\text { Customer } \\
\text { experience }\end{array}$ & Conceptual & $\begin{array}{l}\text { This article focuses on "The Future of Retailing" by highlighting five key areas that are moving the field forward: (1) technology } \\
\text { and tools to facilitate decision making, (2) visual display and merchandise offer decisions, (3) consumption and engagement, } \\
\text { (4) big data collection and usage, and (5) analytics and profitability. }\end{array}$ \\
\hline $\begin{array}{l}\text { Hubert et al } \\
(2017)\end{array}$ & Multichannel & Empirical & $\begin{array}{l}\text { Results demonstrate that several acceptance predictors are associated with ease of use and usefulness, which in turn affect } \\
\text { intentional and behavioural outcomes. They post that flexibility and mobility motivate customers to better understand mobile } \\
\text { shopping and improve ease of use perception. }\end{array}$ \\
\hline $\begin{array}{l}\text { Saghiri, et al } \\
(2017) \text {. }\end{array}$ & Omnichannel & Conceptual & $\begin{array}{l}\text { This paper develops a conceptual framework for omnichannel systems, configured by three dimensions of channel stage, } \\
\text { channel type and channel agent. The researchers highlight the gap in the omni literature, aiming to fulfil this deficiency with a } \\
\text { conceptual holistic omnichannel theoretical framework. }\end{array}$ \\
\hline Bezes (2016) & Multichannel & Empirical & $\begin{array}{l}\text { Identifies customers perceived risks associated between online and offline purchases. Their findings support that customers' } \\
\text { familiarity with the channel seems to make them more vigilant. }\end{array}$ \\
\hline $\begin{array}{l}\text { Huang et al } \\
(2016)\end{array}$ & Multichannel & Empirical & $\begin{array}{l}\text { Results indicate that after the adoption of a mobile channel, the purchases on the web channel were slightly cannibalised, } \\
\text { however, the consumers' purchases increased overall, suggesting that the positive synergy effect of the new channel } \\
\text { overrode the negative cannibalisation effect }\end{array}$ \\
\hline $\begin{array}{l}\text { Lemon } \\
\text { \& Verhoef }(201 \\
6)\end{array}$ & $\begin{array}{l}\text { Customer } \\
\text { experience } \\
\text { Multichannel }\end{array}$ & Conceptual & $\begin{array}{l}\text { Identifies the latest research in customer experience and types of touch points in the customer's journey. Highlights a } \\
\text { research agenda for customer experience, the mapping of a customer's journey across multichannel platforms including } \\
\text { mobile and touchpoints. }\end{array}$ \\
\hline \begin{tabular}{|l|} 
Pantano \& \\
Priporas (2016)
\end{tabular} & $\begin{array}{l}\text { Customer } \\
\text { experience }\end{array}$ & Empirical & $\begin{array}{l}\text { Highlights the increased movement from e-channels to mobile channel and identifies consumer experience creates value for } \\
\text { consumers, by saving them time, money, supporting their lifestyle, offering security in transactions, and offering quality } \\
\text { collection services, which act as drivers of consumer behaviour. }\end{array}$ \\
\hline
\end{tabular}




\begin{tabular}{|c|c|c|c|}
\hline \begin{tabular}{|l|l|} 
Picot- \\
Coupey et al \\
$(2016)$
\end{tabular} & $\begin{array}{l}\text { Multichannel } \\
\text { Omnichannel }\end{array}$ & Empirical & $\begin{array}{l}\text { Highlights the challenges in shifting from a multichannel to Omnichannel strategy. They highlighted the priority challenge } \\
\text { becomes more development-related in order to achieve synchronisation across touch points. In particular, the various } \\
\text { systems (logistics, information, sales, marketing, training, product management) have to be unified. }\end{array}$ \\
\hline $\begin{array}{l}\text { Baxendale et al } \\
(2015)\end{array}$ & Multichannel & Empirical & $\begin{array}{l}\text { Examines the impact on change in brand consideration of six broad touchpoints: brand advertising; retailer advertising; in- } \\
\text { store communications; peer-to-peer conversation; traditional earned media; and peer observation. Also, examines the roles of } \\
\text { both touchpoint frequency and touchpoint positivity in forming this impact. This contributes to multichannel literature and brand } \\
\text { choice. }\end{array}$ \\
\hline \begin{tabular}{|l|l|} 
Beck \\
\& Rygl (2015)
\end{tabular} & $\begin{array}{l}\text { Multichannel } \\
\text { Omnichannel }\end{array}$ & Conceptual & $\begin{array}{l}\text { This article proposes a categorisation of multi, cross and Omnichannel retailing by means of a literature review. Defines } \\
\text { "Omnichannel retailing is the set of activities involved in selling merchandise or services through all widespread channels, } \\
\text { whereby the customer can trigger full channel interaction and/or the retailer controls full channel integration." (p. 175) }\end{array}$ \\
\hline $\begin{array}{l}\text { Melis et } \\
\text { al (2015) }\end{array}$ & Multichannel & Conceptual & $\begin{array}{l}\text { Identifies the drivers of multichannel shoppers' drivers of online store choice decisions. Supports familiarity as a driver of } \\
\text { online choice. The offline experience is important when a customer starts to shop in a new online channel but once familiar } \\
\text { this is less important. Supports that the offline and online needs to be consistent for the customer's experience. }\end{array}$ \\
\hline \begin{tabular}{|l|} 
Pauwels \& Nesi|| \\
in (2015)
\end{tabular} & Multichannel & Empirical & $\begin{array}{l}\text { Develops a multichannel framework examining the impact of channel additions. Introducing a new in-store channel did not } \\
\text { cannibalise online sales as much as catalogue sales. Increasing channel choice increases revenues }\end{array}$ \\
\hline \begin{tabular}{|l|l|l} 
Rapp et \\
al (2015)
\end{tabular} & Multichannel & Empirical & $\begin{array}{l}\text { Investigates the effect of showrooming and multichannel retailing on salesperson self-efficacy and performance. Showrooming } \\
\text { is associated with decreased salesperson performance. Highlights the importance of training staff to cross-sell }\end{array}$ \\
\hline $\begin{array}{l}\text { Verhoef et al } \\
(2015)\end{array}$ & $\begin{array}{l}\text { Multichannel } \\
\text { Omnichannel }\end{array}$ & Conceptual & $\begin{array}{l}\text { Highlights the differences between multichannel and Omnichannel approaches and calls for further research in Omnichannel } \\
\text { and customer experience and the customer's journey. }\end{array}$ \\
\hline \begin{tabular}{l|l|} 
Gallino \& \\
Moreno (2014)
\end{tabular} & Multichannel & Empirical & $\begin{array}{l}\text { Highlights the growing trend of the integration of channels (specifically buying online picking up in store). Results imply the } \\
\text { evaluation of a multichannel strategy should be performed in a holistic way. Their results show that customers clearly see the } \\
\text { company as one entity and not two separate businesses (online vs offline). }\end{array}$ \\
\hline $\begin{array}{l}\text { Avery et } \\
\text { al (2012) }\end{array}$ & Multichannel & Empirical & $\begin{array}{l}\text { Proposes a conceptual framework of the effects of introducing a new channel (bricks and mortar) and how channels can } \\
\text { cannibalise or grow sales across different channels. Highlights the importance of having a brick and mortar store to drive sales } \\
\text { and new customers. }\end{array}$ \\
\hline $\begin{array}{l}\text { Rose et } \\
\text { al (2012) }\end{array}$ & $\begin{array}{l}\text { Customer } \\
\text { experience }\end{array}$ & Empirical & $\begin{array}{l}\text { Highlights the differences between online and office, the way the information is provided is different; the online context } \\
\text { enables very rich provision of information, whereas face to face may be more limited. }\end{array}$ \\
\hline $\begin{array}{l}\text { Rose et al } \\
(2011)\end{array}$ & $\begin{array}{l}\text { Customer } \\
\text { experience } \\
\text { online }\end{array}$ & Conceptual & $\begin{array}{l}\text { Proposed a framework suggesting that an outcome of a positive OCE is customer satisfaction an intention to re-purchase from } \\
\text { a website. The degree of personal contact can range from intensive face to face context to non-existent online. The way the } \\
\text { information is provided is different; the online context enables very rich provision of information, whereas face to face may be } \\
\text { more limited. The time period is different as online customers can purchase at a time or place suited to them. Whereas face to } \\
\text { face is restricted by opening hours. }\end{array}$ \\
\hline $\begin{array}{l}\text { Lemke et al } \\
(2011)\end{array}$ & $\begin{array}{l}\text { Customer } \\
\text { experience }\end{array}$ & Conceptual & $\begin{array}{l}\text { Validates that customers construe experience quality and not just product or service quality and assess their experience } \\
\text { holistically. Customer experience quality includes an assessment not just of communication and service quality but also of } \\
\text { usage quality. }\end{array}$ \\
\hline $\begin{array}{l}\text { Ganesh et } \\
\text { al (2010) }\end{array}$ & Multichannel & Empirical & $\begin{array}{l}\text { Research found there are more similarities than differences among traditional and online customers. There are core factors } \\
\text { that influence shopping irrespective of formats. Points of distinction for e-stores: } 1 \text {. interactivity and the ability to offer } \\
\text { personalised services. 2. ability to redefine convenience. 3. ability to control their website content. }\end{array}$ \\
\hline \begin{tabular}{l|} 
Constantinides \\
et al (2010)
\end{tabular} & $\begin{array}{l}\text { Customer } \\
\text { experience }\end{array}$ & Empirical & $\begin{array}{l}\text { The research found many similarities in the way e-users from both countries consider how the web experience factors affect } \\
\text { their decisions. Familiarity with the online purchase dimension is not a relevant dimension affecting the consumer's } \\
\text { preferences to choose a virtual store. Given that an online consumer is not simply a shopper, but also an information }\end{array}$ \\
\hline
\end{tabular}




\begin{tabular}{|c|c|c|c|}
\hline & & & $\begin{array}{l}\text { technology user (Cho and Park, 2001) one could argue that the online experience is a more complex issue than the physical } \\
\text { shopping experience. }\end{array}$ \\
\hline $\begin{array}{l}\text { Zhang et } \\
\text { al (2010) }\end{array}$ & Multichannel. & Conceptual & $\begin{array}{l}\text { Retailers tend to manage channels separately which causes conflicts. Companies need to analyse data they have about their } \\
\text { customers to understand how they behave across channels. Multichannel strategies must adopt a customer-centric approach } \\
\text { (supporting Verhoef et al., 2010) }\end{array}$ \\
\hline $\begin{array}{l}\text { Verhoef et } \\
\text { al (2009) }\end{array}$ & $\begin{array}{l}\text { Customer } \\
\text { experience } \\
\text { multichannel }\end{array}$ & Conceptual & $\begin{array}{l}\text { Acknowledges multichannel experiences - one channel experience might affect another. Argue that prior customer } \\
\text { experiences can influence future customer experiences. The model includes situational moderators such as the type of store, } \\
\text { location that could impact the customer's experience. }\end{array}$ \\
\hline $\begin{array}{l}\text { Grewal et al } \\
(2009)\end{array}$ & $\begin{array}{l}\text { Customer } \\
\text { experience }\end{array}$ & Conceptual & $\begin{array}{l}\text { This paper highlights the importance of customer experience in retail and identifies the macro factors e.g. promotions, price, } \\
\text { merchandise, supply chain and location to deliver a superior customer experience that results in higher customer satisfaction. } \\
\text { "Customer experience includes every point of contact at which the customer interacts with the business, product, or } \\
\text { service" (p.1). }\end{array}$ \\
\hline \begin{tabular}{|l|l}
$\begin{array}{l}\text { Hahn \& Kim } \\
(2009)\end{array}$ \\
\end{tabular} & Multichannel & Empirical & $\begin{array}{l}\text { A customer's trust with an online retailer was found to be a significant predictor of internet confidence and search intention in } \\
\text { the multichannel retail environment trust. }\end{array}$ \\
\hline $\begin{array}{l}\text { Cassab \& Mac } \\
\text { Lachlan (2009) }\end{array}$ & Multichannel & Conceptual & $\begin{array}{l}\text { This research posits that a customer's evaluation of a multichannel service interface has a strong influence on trust and trust } \\
\text { has a positive effect on commitment, thus enhancing customer loyalty. "The perception of a higher degree of interaction as } \\
\text { represented by the key multichannel service variables is shown to be associated with greater customer trust to organisations } \\
\text { that make the interaction seamless across customer touch points" (p. 66). }\end{array}$ \\
\hline $\begin{array}{l}\text { Neslin \& } \\
\text { Shankar } \\
\text { (2009) }\end{array}$ & Multichannel & Empirical & $\begin{array}{l}\text { Channel-based customer segmentation is advisable. Customers have different preferences for channel usage and inertia } \\
\text { affects their channel choices. Multichannel availability may enhance loyalty. }\end{array}$ \\
\hline $\begin{array}{l}\text { Kukar-Kinney } \\
\text { et al (2009) }\end{array}$ & $\begin{array}{l}\text { Customer } \\
\text { experience } \\
\text { online }\end{array}$ & Empirical & $\begin{array}{l}\text { When customer's compulsive buying needs increased, they are more motivated to buy online compared to in-store. The } \\
\text { motivation is stemmed from being anonymous online and avoids social interaction whilst shopping plus the positive feelings } \\
\text { associated with shopping online. Retailers should develop exciting and interactive sites to stimulate positive feelings. }\end{array}$ \\
\hline $\begin{array}{l}\text { Verhoef et al } \\
(2007)\end{array}$ & Multichannel & Empirical & $\begin{array}{l}\text { There is a mutual relationship between attitudes towards searching and purchasing in a channel - channel lock-in. If there is a } \\
\text { lack of channel locks-in - cross channel synergy. Findings conclude that Internet-store research shopping is the most } \\
\text { common form. This can be reduced by improving service and privacy and security in purchasing online), by managing channel } \\
\text { lock-in and cross-channel synergy. }\end{array}$ \\
\hline $\begin{array}{l}\text { Parasuramen } \\
\text { et al (2005) }\end{array}$ & $\begin{array}{l}\text { Customer } \\
\text { experience }\end{array}$ & Empirical & $\begin{array}{l}\text { Concludes that efficiency and fulfilment are the most crucial and important dimensions for website service quality. These } \\
\text { dimensions had the strongest influence on overall quality perceptions and perceived value and loyalty intentions. }\end{array}$ \\
\hline \begin{tabular}{l|} 
Schoenbachler \\
\& Gordon \\
(2002)
\end{tabular} & Multichannel & Conceptual & $\begin{array}{l}\text { The model proposes that the more familiar the customer is with Internet brand or company the lower the perceived } \\
\text { risk. Customers channel preferences must be researched to understand their behaviours and the multichannel buyers. The } \\
\text { focus must be on the customer and design channel alternatives to satisfy their needs. }\end{array}$ \\
\hline \begin{tabular}{l|l} 
Novak et al \\
$(2000)$
\end{tabular} & $\begin{array}{l}\text { Customer } \\
\text { experience }\end{array}$ & Empirical & $\begin{array}{l}\text { Website design must provide for enough challenge to arouse the consumer but not too much to be frustrated through } \\
\text { navigating the site and logs off. Engaging customers online will arouse excitement. If the site does provide enough challenges } \\
\text { for action, customers will become bored and log off. A compelling online customer experience is positively correlated with fun, } \\
\text { recreational and experiential uses of the web, expected use of the web in the future and the amount of time consumers spend } \\
\text { online. }\end{array}$ \\
\hline
\end{tabular}




\section{Conceptual Framework}

Underpinned by a review of the extant literature, our conceptual framework (see Figure 1) proposes that four constructs act as the factors that influence omnichannel: brand familiarity, customisation, perceived channel value, and technology readiness. We posit that retailers need to establish a greater understanding of these antecedents to manage their omnichannel more effectively. Furthermore, we suggest that omnichannel is not one entity, but it is an integration of multiple channels, and we argue the seamless combination of these channels is the omnichannel. We recognise there are multiple touchpoints and channels that a customer can interact with a retailer, from drawing the arguments together, we conceptualise omnichannel as online, instore and mobile.

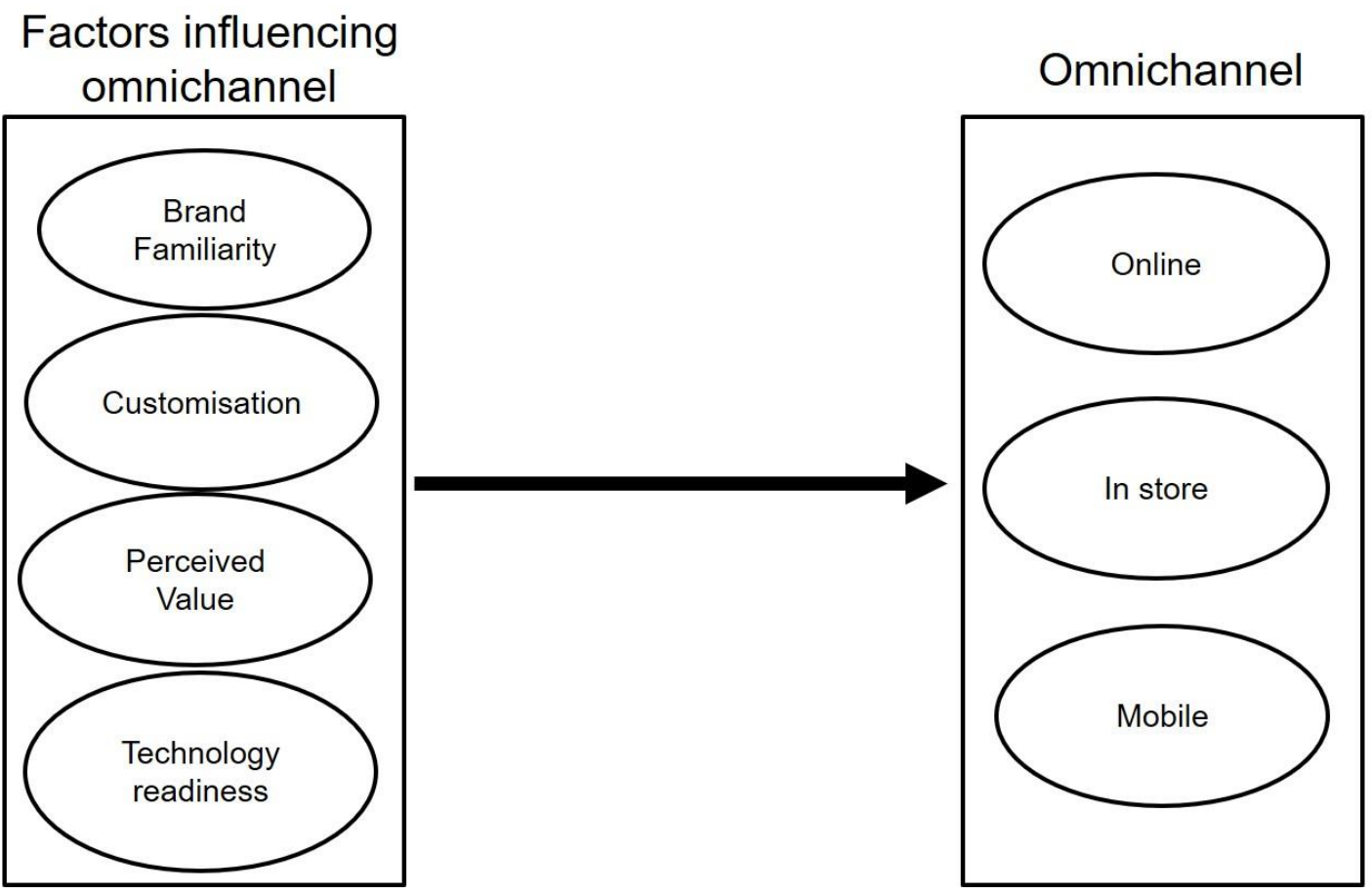

Figure 1. Conceptual framework 


\section{Antecedents of omnichannel}

Relationship between brand familiarity and an omnichannel experience

Park and Stoel $(2005,150)$ define brand familiarity as "the number of brandrelated direct or indirect experiences that have been accrued by the consumer". Hoch and Deighton (1989) posit that brand familiarity directly relates to the amount of time customers spend processing information about the brand, while earlier Baker et al (1986) noted that this was regardless of the type or content of the processing involved. The benefits of establishing brand familiarity stem from the assumption that consumers are more likely to purchase familiar brands over none familiar ones (Park and Stoel, 2005). Brand familiarity is the antecedent to intention to buy the brand through the high level of confidence toward the brand (Laroche, Kim and Zhou1996). Bezes (2016) finds that the more familiar the customer is with a channel, seems to make them more vigilant.

Customers find it easier to retrieve and store information and demonstrate less effort in processing information about familiar brands (Dahlen and Lange, 2004). Research indicates that brand familiarity reduces the need for information search, as illustrated by Biswas's (1992) study which highlights that customers tend to spend less time shopping for a familiar brand than they do for an unfamiliar brand. Familiarity also appears as a necessary, although not sufficient, condition for the development of expertise and the ability to perform product-related tasks successfully (Ha and Perks, 2005). Ultimately, brand familiarity is crucial when creating more awareness around the brand, which can illicit more favourable responses to towards them (DelgadoBallester, Navarro and Sicilia2012), and impact upon a customer's decision to purchase (Lin, 2013). 
Delgado-Ballester, Navarro and Sicilia (2012) suggests that sending out consistent messages that excite customers about the brand is important in building brand familiarity. Raymond, Fenske and Westoby (2005) argued that too much familiarity with a brand could lead to a decrease in the liking of them due to overexposure. Moreover, if there is a positive perception of the brand, the feelings of satisfaction or trust will be greater than if there is a negative perception of the brand (Ha and Perks, 2005). Keller (2003) puts forward the notion that brand familiarity can reduce a customer's perceived risk when deciding whether to purchase from an organisation. However, Pauwels et al (2016) results indicate that when a brand is unfamiliar it must use multiple channels to build brand equity as online only is not effective.

Schoenbachler and Gordon, 2002 argues that to successfully promote a brand in a multichannel environment there must a consistent brand image across all channels. Although there is sparse research on brand familiarity across different channels, our research identifies brand familiarity as an antecedent to an omnichannel experience and we argue that:

$\mathrm{H}_{1}$ : brand familiarity has a positive effect on an omnichannel experience:

$\mathrm{H}_{1 \mathrm{a}}$ : brand familiarity has a positive effect on online experience.

$\mathrm{H}_{1 \mathrm{~b}}$ : brand familiarity has a positive effect on in-store experience.

$\mathrm{H}_{1 \mathrm{c}}$ : brand familiarity has a positive effect on mobile experience.

Relationship between customisation and an omnichannel experience 
Marketing messages should be customer focused (Klaus and Maklan 2013) and retailers need to calculate customer profitability by segmenting their customer's and drive customised messages (Kumar, Petersen and Leone 2010). Perceived customisation refers to the extent to which the responses of communicative information systems are perceived as appropriate or personally relevant to a user's communicative behaviours (Lee et al 2015). Customisation in retail integrates customer data with the use of advanced customer analytics to provide insight and enhance the customer experience (Parise, Guinan and Kafka 2016). The earlier work by Coelho and Henseler, (2012) supports these findings by indicating that customising the service delivery will lead to customer satisfaction and loyalty.

The stimuli from digital technology through any channel can influence customers' behaviour due to interactivity. Liang et al (2011) support these findings and argue that customisation leads to a positive customer attitude to the brand because they feel valued by the company. Avery et al (2012) also advocate the importance of keeping a consistent message throughout all channels to maintain a better customer brand perception.

Customisation occurs more frequently online than in-store, as retailers can easily track, store and customise information about their customers, e.g. customers can open an account, store their data etc. (Liang et al 2011; Avery et al 2012). Therefore, the design of websites needs to engage customers to increase arousal and action (Novak, Hoffman and Yung 2000). The in-store experience also needs to be consistent with the online presence of the retailer. We have therefore posited that:

$\mathrm{H}_{2:}$ Customisation has a positive effect on an omnichannel experience:

$\mathrm{H}_{2 a}$ : Customisation has a positive effect on online experience. 
H2b: Customisation has a positive effect on mobile experience.

Relationship between perceived value and an omnichannel experience

Perceived value is often positioned at the heart of the customer experience (McDougall and Levesque, 2000) with perceived value being the results or benefits customers receive in relation to total costs. The customer's perceived value is the difference between the benefits and costs offered by a retailer; however, this value is subjective and can differ from one to customer to another (McDougall and Levesque, 2000). Sanchez et al (2006) highlights the holistic nature of how a customer perceives value including both the cognitive and effective elements that affect the overall perceived value of a purchase. A service's perceived value adds to a customer's overall satisfaction that is fundamental for a company as it plays a fundamental role in their success (Iglesias and Guillén, 2004). Carlson, O'Cass and Ahrholdt (2015) highlight the importance of service quality and argue this is the largest contribution to online perceived value.

McDougall and Levesque, (2000) posit that perceived value is a key determinant of customer satisfaction and contend that perceived value should be included in customer satisfaction models. Taken in its entirety, as a key concept, perceived value may be a better predictor of repurchase intentions than either satisfaction or quality (Cronin, Brady and Hult 2000). Value is not embedded in a product at the moment of exchange but, rather, is obtained through use processes (Tynan, McKechnie and Chhuon 2010). Therefore, we argue if customer perceive channel importance, they are more likely to perceive the importance of the seamless approach to the omnichannel. We, thus, propose:

$\mathrm{H}_{3}$ : Perceived value has a positive effect on an omnichannel experience: 
$\mathrm{H}_{3 a}$ : Perceived value has a positive effect on online experience.

$\mathrm{H}_{3 b}$ : Perceived value has a positive effect on in-store experience.

$\mathrm{H}_{3 c}$ : Perceived value has a positive effect on mobile experience.

Relationship between technology readiness and omnichannel experience

Technology readiness is the "people's propensity to embrace and use new technologies for accomplishing goals in home life and at work" (Parasuraman, 2000, 308). With new and improved technologies penetrating the market increasingly, the need to understand customers' perception and acknowledgement towards it is vital (Parasuraman, 2000). Retailers are embracing technologies in-store, customer service staff are utilising tablets to enhance service delivery (Chandrawati and Lau, 2016). Adding to prior work on technology acceptance, Parasuraman, (2000) postulates that the likelihood of customers engaging with new technology is dependent on the customer's willingness to explore new capabilities of technology, but also their potential inhibitions surrounding the lack of perceived control and/or trust with new technology (Rose et al 2012). Notwithstanding the earlier viewpoint, Pantano's, (2013) research found that there is a natural expectation on the part of customer that businesses have to adopt newer forms of technology to improve a customer's overall shopping experience because their expectations are elevated (Blazquez, 2014).

Parasuraman and Colby, (2016) constructed a 16-item scale identifying a customer spectrum of technology readiness. Their research highlights that different technological capabilities appeal to different customers and the customer's experience that be significantly affected by a company's advancements in technology use in-store. Juaneda-Ayensa, Mosquera and Sierra Murillo (2016) identified the key drivers of 
technology readiness to be personal innovativeness, effort expectancy and performance expectancy and support that acceptance and intention to use new technologies influences an omnichannel customer's behaviour. We maintain the viewpoint that the less technology ready customers are, the less likely they will perceive a seamless approach to omnichannel. Therefore, we propose that:

$\mathrm{H}_{4}$ : Technology readiness has a positive effect on online experience:

$\mathrm{H}_{4 \mathrm{a}}$ : Technology readiness has a positive effect on online experience.

$\mathrm{H}_{4 b}$ : Technology readiness has a positive effect on in-store experience.

$\mathrm{H}_{4 c}$ : Technology readiness has a positive effect on mobile experience.

\section{Research Design}

This study used a two-part approach - firstly, interviewing 11 marketing professionals and secondly, using an online survey which was emailed to participants via social media and professional networks in the UK. Participants were screened on the basis that they shopped in a high-street shop, have a smart phone and have shopped online previously. This was essential to determine the effect of each omnichannel approach on the participants.

\section{Interview selection and results}

This study was conducted between 2016 and 2017 using a two-part approach that began with interviewing 11 omnichannel marketing professionals who are responsible for either managing a multichannel or omnichannel strategy. Interviews were held in the UK and all professionals worked in organisations that had either implemented or were in the process of adopting an omnichannel approach. The 
interviews lasted on average between 30 to 60 minutes and the aim was to establish the industry perceptions of key challenges facing the implementation of omnichannel. The results of the interviews aided the construction of the conceptual model.

Results from the interviews highlighted that omnichannel was not being managed effectively by retailers. An omnichannel expert interviewed mentioned that "customers don't see on/off line as separate. The ideal customer journey allows them to select a product on line, go to a store to try it on or order online. It's seamless and integrated'. Channels were being managed separately and retailers needed to have a consistent approach across all channels, one marketing manager stated that "many retailers manage their channels separately, having Directors of online, mobile and instore competing and cannibalising profitability". Marketing professionals also highlighted that the customer needed to be the central pivot of an omnichannel experience not the specific channel "customers are less brand loyal than they used to be, an omnichannel approach amplifies our messages to our target audiences, which in turn helps us to deliver a more synergistic brand reputation - whether you're in-store, online or on a mobile device". The predominant channels emerged as online, mobile and in-store, although other touchpoints were identified as important and worthy of investigation.

The findings from the interviews with the marketing professionals underpinned the quantitative study. Using a snowball approach, we used an online survey to recruit participants via social media and professional networks in the UK. Participants were screened on the basis that they shopped in a high-street shop, have a smart phone and have shopped online previously. This was essential to determine the effect of each omnichannel approach on the participants. While snowballing sampling, like most 
sampling techniques, is not without its flaws, Faugier and Sergeant, (1997) note that snowball it is an acceptable methodology for drawing conclusions. The survey instrument was administrated through a web-based survey, using Qualtrics. We utilised a web-based survey over a more traditional paper-based approach because of the advantages that it presents.

Despite some of the disadvantages of using online surveys such as low response rate, lack of personalisation and privacy issues, Evans and Mathur (2005) and Göritz (2004) found that a well conducted online survey has far more advantages over other methods of survey data collection, this is mainly due to online survey global reach, flexibility and speed (see Evans and Mathur 2005 for more comprehensive analysis of the pros and cons of online surveys).

\section{Questionnaire Measures}

Measures from well-established scales were adopted when applicable, which Netemeyer Bearden and Sharma (2003) argue is an acceptable approach. Technology readiness was measured using six items adapted from Parasuraman and Colby, (2016). Brand familiarity was measured using four items adapted from Park and Stoel, (2005) and Brakus, Schmitt and Zarantonello (2009). Five items used to measure perceived value based on the work of Tynan McKechnie and Chhuon (2010). Customisation was captured using four items from Kumar, Petersen and Leone, (2010) and Parise Guinan and Kafka (2016). All the items and their sources are in Appendix 1.

The dependent constructs of the model were operationalised and measured based on participants' usage of these constructs. High street shopping typically involves a physical location, a building that shoppers can visit, often referred to as 
bricks and mortar shops. High street shopping is viewed as being more tangible than online shopping as a consequence of its physical location and attached sensory cues (Rajamma, Paswan and Ganesh 2007). Mobile shopping refers to all "the activities of consumers who use wireless Internet service when shopping and purchasing via a mobile phone" (Ko, Kim and Lee 2009, 671). Online shopping activity is performed by a customer via a computer-based interface using a retailer's digital storefront (website) (Häubl and Trifts, 2000). Therefore, we asked the survey participants specific questions for each of these approaches. The construct of the high street usage was measured with three items adapted from Babin, Darden and Griffin (1994), mobile usage was measured with three items adapted from Sohn (2017) and online usage was measured with four adapted items from Rose et al (2012).

\section{Findings}

In total 246 responses were collected. The sample characteristic is $74 \%$ female and $26 \%$ male. The age distribution of the respondents is $18-24$ (35.8\%), $25-34$ (9.8\%), 35-44 (29.5\%), 45-54 (10.4\%), 55-64 (7.5\%) and 65-74 (6.9\%). There were no statistical differences between gender and between the different age groups.

\section{Measurement Model}

Data analysis was conducted using SmartPLS 3. We started assessing the measurement model by examining the internal consistency, convergent validity and discriminant validity of the model. The results of the Composite Reliability $(C R)$ of each of the seven constructs were above the recommended threshold of 0.6 (see Bagozzi and $\mathrm{Yi}, 1988)$. The $\mathrm{CR}$ ranged from .93 for customisation to .79 for brand familiarity (see Table 2). Furthermore, during this stage we evaluated the construct validity and all our proposed constructs met the standard tests for convergent and discriminant 
validity. The average variance extracted (AVE) of each construct was above Bagozzi and Youjae's, (1988) recommended 0.5 threshold. In addition, each of the measurement items were all above .5 (see Appendix 1 for the full report of item loadings). We further tested for discriminant validity using the corresponding $95 \%$ bias corrected and accelerated $(\mathrm{BCa})$ confidence interval of the heterotrait-monotrait (HTMT) ratio of correlations statistic (Henseler, Ringle and Sarstedt 2016), the results show that there are no construct that are highly correlated, indicating that the discriminant validity have been achieved (see Table 2).

Table 2 - HTMT test for discriminant validity, composite reliability, AVE

\begin{tabular}{|c|c|c|c|c|c|c|c|c|}
\hline & CR & AVE & $\begin{array}{l}\text { Brand } \\
\text { Familiarity }\end{array}$ & $\begin{array}{l}\text { High } \\
\text { Street }\end{array}$ & Mobile & Online & $\begin{array}{l}\text { Perceived } \\
\text { value }\end{array}$ & Customisation \\
\hline $\begin{array}{l}\text { Brand } \\
\text { Familiarity }\end{array}$ & 0.79 & 0.56 & - & & & & & \\
\hline High Street & 0.8 & 0.50 & 0.43 & - & & & & \\
\hline Mobile & 0.79 & 0.56 & 0.18 & 0.29 & - & & & \\
\hline Online & 0.84 & 0.50 & 0.22 & 0.33 & 0.16 & - & & \\
\hline $\begin{array}{l}\text { Perceived } \\
\text { value }\end{array}$ & 0.87 & 0.64 & 0.30 & 0.27 & 0.46 & 0.36 & - & \\
\hline Customisation & 0.83 & 0.54 & 0.42 & 0.21 & 0.2 & 0.42 & 0.35 & - \\
\hline $\begin{array}{l}\text { Tech } \\
\text { Readiness }\end{array}$ & 0.93 & 0.70 & 0.25 & 0.15 & 0.42 & 0.33 & 0.48 & 0.3 \\
\hline
\end{tabular}

\section{Results of Structural Model}

The assessment of the structural model was initiated by examining the VIF values, which indicate the multicollinearity between the constructs, if they are above the recommended threshold of 5 . In addition, we ran a blindfolding procedure to assess the predictive power of the model with an omission distance of eight, the results of the cross-validated redundancy values $Q^{2}$ were all above the recommended threshold of zero, indicating the model's predictive accuracy. The $\mathrm{F}^{2}$ values showed 
good effect for the latent factors (high street .94, mobile 1.19 and online .33), The results was also supported by the $Q^{2}$ values (high street .14 , mobile .21 and online .21 ), why the $R^{2}$ values (high street .49 , mobile .52 and online .24) which according to Schlägel and Sarstedt (2016) allows to draw the conclusion that the model has a satisfactory in-sample predictive power.

The assessment of the path coefficient indicates that brand familiarity has a negative non-significant effect (.24) on online $\beta=-0.3$ rejecting $H_{1 a}$, whilst brand familiarity has the highest positive and significant (.05) impact on in-store touchpoint $\beta=0.3$ and positive significant (.05) impact on mobile $\beta=.10$ enabling us to accept $\mathrm{H}_{1 \mathrm{~b}}$ and $\mathrm{H}_{1 \mathrm{c}}$. Customisation has a positive and significant (.05) impact on mobile $\beta=$ 0.12 and online $\beta=0.34$ supporting $\mathrm{H}_{2 a}$ and $\mathrm{H}_{2 b}$. the path coefficients indicate that perceived value has a positive and significant (.01) effect on in-store touchpoint $\beta=$ 0.2 , and positive and significant (.05) effect on online $\beta=0.11$ supporting $\mathrm{H}_{3 a}$ and $\mathrm{H}_{3 b}$. However, perceived value had a negative non-significant (.09) impact on mobile $\beta=$ 0.31 rejecting $\mathrm{H}_{3 c}$. Technology readiness has non-significant effect (.21) on the instore $\beta=-0.06$ rejecting $H 4 b$, but a positive significant (.01) effect on online $\beta=.15$ and mobile $\beta=.26$ accepting $\mathrm{H}_{4 a}$ and $\mathrm{H}_{4 c}$.

\section{Conclusion and managerial implications}

A combination of economic turbulence (e.g. Berry et al 2010) coupled with evolving customer needs has caused the operating models of retailers to adapt to reach new customers. Against the fluid backdrop this study's overarching objective is to provide an improved understanding of omnichannel retailing and customer experience. This paper contributes to theory by presenting and empirically testing a conceptual framework identifying the factors that influence an omnichannel 
experience. Our proposed framework positions the factors that influence omnichannel experience to be: brand familiarity; customisation; perceived value and technology readiness. We position omnichannel retailing as a holistic experience across high street, mobile and online. Our results show that retailers need to consider multiple antecedents of omnichannel and plan the use of multiple touchpoints simultaneously to enhance their overall customer's experience.

Until recent times retailers often operate in silos (Gallino and Moreno, 2014) and as omnichannel retailing is now taking over from multichannel there are compelling reasons why the customers experience a consistent holistic experience with a retailer. Although there is a body of research evaluating a multichannel experience (e.g. Berman and Thelen, 2004), these channels cannot work in a silo and need to be integrated to provide the customer with a consistent unified experience. As highlighted in recent papers, see Ailawadi and Farris (2017); Verhoef, Kannan and Inman (2015), there is limited research into omnichannel and how it effects the customer experience. The current empirical literature is focussed more on the supply chain and logistics of omnichannel rather than the factors that influence the experience. With the shortcoming of academic research regarding the factors of omnichannel retailing and customer experience we position this framework as a tool to stimulate further research and deepen our understanding of omnichannel. The management on omnichannel is complicated and required to understand several factors for each touchpoint.

Our findings indicate that brand familiarity has a strong influence on the omnichannel (in-store and mobile), thus supporting Delgado-Ballester, Navarro and Sicilia's (2012) findings. Our research shows that retailers need to consider brand familiarity when managing Omni in-store and mobile perhaps by using prominent logos 
and distinct colours, implies that marketing has a central role to play. Nevertheless, when it comes to online it is less likely to have an effect, as our result demonstrate. An explanation for this is that online shoppers' display greater price sensitivity (see Degeratu and Rangaswamy 2000), when shopping online customers are price sensitive and they are exhibiting some habitual purchasing behaviour, e.g. buying for Amazon without making comparisons. In such a situation, they are less likely to respond to strong brand focus messages. Although this is the case, behaviourally online shopping does provide an easier environment within which to switch (Reibstein, 2002).

Allowing customers to customise their apps or websites has a strong positive effect on omnichannel. Our results support Parise Guinan and Kafka (2016) by demonstrating that customisation enriches a customer's experience. Our results also allow us to maintain that customisation is more pertinent to online and mobile touchpoints (Liang et al 2011). Retailers need to use the latest technology and customer data to understand their shopping behaviour and personalise their experience whilst maintaining a seamless experience.

Our results illuminate the position that when, as part of the overall customer experience, customers perceived a value in using the online touchpoint or the in-store touchpoint they are more likely to engage positively with omnichannel. Retailers should emphasise on building key messages when encouraging their customers to engage with different touchpoints. Where an omnichannel approach exists, the information provided is important to inform customers (Bell, Gallino and Mereno 2014). For example, retailers should provide an incentive for customers to use in-store touchpoints such as a percentage discount on purchases. 
The use of technology has transformed many business areas (Roy et al 2016) but in the case of our study technology readiness does not have a significant effect on the in-store touchpoint. We argue that this is mainly due to customers relying on staff to assist them. However, congruent with Parasuraman and Colby's (2016) assertion, technology readiness has a positive impact on mobile and online. This requires retailers to assess the extent their customers are ready to use technologies and provide help and technical support. The use of online chatbots or live chat can facilitate this.

\section{Limitations and future research opportunities}

Caution should be used in interpreting and generalising the results of this study. Although this study is valuable in demonstrating the causal factors of omnichannel customer experience, questions remain regarding the exact use of each touchpoint and the extent of their overlap. Such concern calls for further investigation into the relative importance of omnichannel drivers. We would encourage future research to examine the effect of different constructs to this study on omnichannel, e.g. type of retailer or previous satisfaction experiences. Future researchers are also encouraged to explore moderating factors on omnichannel experience, such as store incentives or family and friends influence. This study only focused on two industries and was conducted in the UK, future researchers could apply and test the model in other cultures and on different industries.

The study's methodology has its limitations. For example, we use cross sectional survey data which does not provide a long-term view of customer attitudes and behaviours towards omnichannel. The use of a longitudinal panel will enable evolving behaviour to be monitored. We recognise that despite our attempt to collect an even 
distribution data, our sample does not have a perfect gender breakdown. Our research also did not consider the effect of different types of retailers on omnichannel, as some customers are more likely to engage with different touchpoints depending on the type of retailer, we asked customers to reflect on a previous shopping experience from a supermarket or clothing multi-channel retailer, this experience could be different by industry type. Further research could investigate the omnichannel objectives of a retailer and compare them to the perception of customers, this will allow retailers to understand how their customer perceives and gets value from omnichannel. We encourage further research into the link between customer journey and omnichannel, in particular how customers' behaviour and perceptions change throughout their journey with a retailer. 


\section{References}

Ailawadi, K. L., and Farris, P. W. (2017). "Managing Multi-and omnichannel Distribution: Metrics and Research Directions". Journal of Retailing, 93(1), pp120-135.

Anon, (2018). "Online Retailing: Britain, Europe, US and Canada 2017". Centre for Retail Research [online] available from:

http://www.retailresearch.org/onlineretailing.php [05th June 2018].

Avery, J., Steenburgh, T. J., Deighton, J., and Caravella, M. (2012). "Adding bricks to clicks: Predicting the patterns of cross-channel elasticities over time". Journal of Marketing, 76(3), pp96-111.

Babin, B. J., Darden, W. R., and Griffin, M. (1994). "Work and/or fun: measuring hedonic and utilitarian shopping value”. Journal of Consumer Research, 20(4), pp644-656.

Bagozzi, R. P., and Youjae, Yi. (1988). "On the Evaluation of Structural Equation Models" Journal of the Academy of Marketing Science, 16(1), pp74.

Baker, W., Hutchinson, J., Moore, D., and Nedungadi, P. (1986). "Brand familiarity and advertising: effects on the evoked set and brand preference". NA-Advances in Consumer Research, 13.

Barwitz, N., and Maas, P. (2018). Understanding the Omnichannel customer journey: determinants of interaction choice. Journal of Interactive Marketing, 43, 116133.

Baxendale, S., Macdonald, E. K., and Wilson, H. N. (2015). "The impact of different touchpoints on brand consideration”. Journal of Retailing, 91(2), pp235-253.

Beck, N., and Rygl, D. (2015). "Categorization of multiple channel retailing in Multi-, Cross-, and Omni-Channel Retailing for retailers and retailing". Journal of Retailing and Consumer Services, 27, pp170-178.

Bell, D. R., Gallino, S., and Moreno, A. (2014). "How to win in an omnichannel world". MIT Sloan Management Review, 56(1), pp45-53.

Berman, S. J., and Kesterson-Townes, L. (2012). "Connecting with the digital customer of the future". Strategy and Leadership, 40(6), pp29-35. 
Berman, B., and Thelen, S. (2004). "A guide to developing and managing a wellintegrated multi-channel retail strategy". International Journal of Retail and Distribution Management, 32, (3), pp147-156.

Berry, L. L., Bolton, R. N., Bridges, C. H., Meyer, J., Parasuraman, A. and Seiders, K. (2010). "Opportunities for innovation in the delivery of interactive retail services". Journal of Interactive Marketing, 24(2), pp155-167.

Bezes, C. (2016). "Comparing online and in-store risks in multichannel shopping". International Journal of Retail and Distribution Management, 44(3), pp284-300.

Biswas, A. (1992). "The moderating role of brand familiarity in reference price perceptions". Journal of Business Research, 25(3), pp251-262.

Brakus, J. J., Schmitt, B. H., and Zarantonello, L. (2009). "Brand experience: what is it? How is it measured? Does it affect loyalty?". Journal of Marketing, 73(3), pp52-68.

Cao, L. and Li, L., 2015. The impact of cross-channel integration on retailers' sales growth. Journal of Retailing, 91(2), pp.198-216.

Carlson, J., O'Cass, A., and Ahrholdt, D. (2015). Assessing customers' perceived value of the online channel of multichannel retailers: A two country examination. Journal of Retailing and Consumer Services, 27, 90-102.

Cassab, H., and MacLachlan, D. L. (2009). "A consumer-based view of multi-channel service". Journal of Service Management, 20(1), pp52-75.

Coelho, P. S., and Henseler, J. (2012). "Creating customer loyalty through service customisation". European Journal of Marketing, 46(3/4), pp331-356.

Constantinides, E., Lorenzo-Romero, C., and Gómez, M. A. (2010). "Effects of web experience on consumer choice: a multicultural approach". Internet Research, 20(2), pp188-209.

Cronin, J. J., Brady, M. K., and Hult, G. T. M. (2000). "Assessing the effects of quality, value and customer satisfaction on consumer behavioral intentions in service environments". Journal of Retailing, 76(2), pp193-218. 
Dabholkar, P. A., Thorpe, D. I., and Rentz, J. O. (1995). "A measure of service quality for retail stores: scale development and validation". Journal of the Academy of Marketing Science, 24(1), pp3-16.

Dahlén, M., and Lange, F. (2004). "To challenge or not to challenge: Ad-brand incongruency and brand familiarity". Journal of marketing theory and practice, 12(3), pp20-35.

Degeratu, A. M., Rangaswamy, A., and Wu, J. (2000). "Consumer choice behaviour in online and traditional supermarkets: The effects of brand name, price, and other search attributes". International Journal of Research in Marketing, 17(1), pp55-78.

Delgado-Ballester, E., Navarro, A. and Sicilia, M. (2012). "Revitalising brands through communication messages: the role of brand familiarity". European Journal of Marketing, 46(1/2), pp31-51.

Einav, L., Levin, J., Popov, I., and Sundaresan, N. (2014). "Growth, adoption, and use of mobile E-commerce". The American Economic Review, 104(5), pp489494.

Evans, J. R., and Mathur, A. (2005). The value of online surveys. Internet research, 15(2), 195-219.

Faugier, J., and Sargeant, M. (1997). "Sampling hard to reach populations". Journal of Advanced Nursing, 26, pp790-797.

Friedman, L. G., and Furey, T. R. (2003). "The channel advantage". Burlington, MA: Butterworth-Heinemann.

Galipoglu, E., Kotzab, H., Teller, C., Yumurtaci Hüseyinoglu, I. Ö., and Pöppelbuß, J. (2018). Omni-channel retailing research-state of the art and intellectual foundation. International Journal of Physical Distribution \& Logistics Management, 48(4), 365-390.

Gallino, S., and Moreno, A. (2014). "Integration of online and offline channels in retail: The impact of sharing reliable inventory available information". Management Science, 60(6), pp1431-1451. 
Ganesh, J., Reynolds, K. E., Luckett, M., and Pomirleanu, N. (2010). "Online shopper motivations, and e-store attributes: an examination of online patronage behaviour and shopper typologies”. Journal of Retailing, 86(1), pp106-115.

Göritz, A. S. (2004). "The impact of material incentives on response quantity, response quality, sample composition, survey outcome, and cost in online access panels". International Journal of Market Research, 46(3), pp411-425.

Grewal, D., Levy, M., and Kumar, V. (2009). "Customer experience management in retailing: an organizing framework". Journal of Retailing, 85(1), pp1-14.

Grewal, D., Roggeveen, A. L., and Nordfält, J. (2017). "The future of retailing". Journal of Retailing, 93(1), pp1-6.

Gudergan, S. P., Ringle, C.M., Wende, S., and Will, A. (2008). "Confirmatory tetrad analysis in PLS path modeling," Journal of Business Research, 61(12), pp1238-49.

Ha, H.Y., and Perks, H. (2005). "Effects of consumer perceptions of brand experience on the web: Brand familiarity, satisfaction and brand trust". Journal of Consumer Behaviour, 4(6), pp438-452.

Hahn, K. H., and Kim, J. (2009). "The effect of offline brand trust and perceived internet confidence on online shopping intention in the integrated multi-channel context”. International Journal of Retail and Distribution Management, 37(2), pp126-141.

Häubl, G., and Trifts, V. (2000). "Consumer decision making in online shopping environments: The effects of interactive decision aids". Marketing Science, 19(1), pp4-21.

Henseler, J., Ringle, C. M., and Sarstedt, M. (2016), “Testing measurement invariance of composites using partial least squares," International Marketing Review, 33(3), pp405-31.

Hoch, S. J., and Deighton, J. (1989). "Managing what consumers learn from experience". The Journal of Marketing, pp1-20.

Hsiao, C. C., Yen, H. J. R., and Li, E. Y. (2012). "Exploring consumer value of multichannel shopping: a perspective of means-end theory". Internet Research, 22(3), pp318-339. 
Huang, Y., and Oppewal, H. (2006). "Why consumers hesitate to shop online: An experimental choice analysis of grocery shopping and the role of delivery fees". International Journal of Retail and Distribution Management, 34(4/5), pp334353.

Hubert, M., Blut, M., Brock, C., Backhaus, C., and Eberhardt, T. (2017). "Acceptance of Smartphone-Based Mobile Shopping: Mobile Benefits, Customer Characteristics, Perceived Risks, and the Impact of Application Context". Psychology and Marketing, 34(2), pp175-194.

Iglesias, M. P., and Guillén, M. J. Y. (2004). "Perceived quality and price: their impact on the satisfaction of restaurant customers". International Journal of Contemporary Hospitality Management, 16(6), pp373-379.

Juaneda-Ayensa, E., Mosquera, A., and Sierra Murillo, Y. (2016). Omnichannel customer behavior: key drivers of technology acceptance and use and their effects on purchase intention. Frontiers in psychology, 7, 1117.

Keller, K. L. (2003). “Understanding brands, branding and brand equity”. Interactive Marketing, 5(1), pp7-20.

Kim, Y. K., Park, S. H., and Pookulangara, S. (2005). "Effects of multi-channel consumers' perceived retail attributes on purchase intentions of clothing products". Journal of Marketing Channels, 12(4), pp23-43.

Klaus, P., and Maklan, S. (2013). "Towards a better measure of customer experience". International Journal of Market Research, 55(2), pp227-246.

Ko, E., Kim, E. Y., and Lee, E. K. (2009). "Modeling consumer adoption of mobile shopping for fashion products in Korea". Psychology and Marketing, 26(7), pp669-687.

Kukar-Kinney, M., Ridgway, N. M., and Monroe, K. B. (2009). "The relationship between consumers' tendencies to buy compulsively and their motivations to shop and buy on the internet”. Journal of Retailing, 85(3), pp298-307.

Kumar, V., Petersen, J. A., and Leone, R. P. (2010). "Driving profitability by encouraging customer referrals: who, when, and how". Journal of Marketing, 74(5), pp1-17. 
Kumar, V., and Venkatesan, R. (2005). "Who are the multi-channel shoppers and how do they perform? Correlates of multi-channel shopping behaviour". Journal of Interactive Marketing, 19(2), pp44-62.

Liang, Q., Wu, X., Park, E.K., Khoshgoftaar, T.M. and Chi, C.H., 2011. Ontologybased business process customization for composite web services. IEEE Transactions on Systems, Man, and Cybernetics-Part A: Systems and Humans, 41(4), pp.717-729.Lee, D., Moon, J., Kim, Y. J., and Mun, Y. Y. (2015). "Antecedents and consequences of mobile phone usability: Linking simplicity and interactivity to satisfaction, trust, and brand loyalty". Information and Management, 52(3), pp295-304.

Lemon, K. N., and Verhoef, P. C. (2016). "Understanding customer experience throughout the customer journey". Journal of Marketing, 80(6), pp69-96.

Laroche, M., Kim, C. and Zhou, L. (1996). "Brand familiarity and confidence as determinants of purchase intention: An empirical test in a multiple brand context". Journal of Business Research, 37(2), pp115-120.

Lemke, F., Clark, M., and Wilson, H. (2011). "Customer experience quality: an exploration in business and consumer contexts using repertory grid technique". Journal of the Academy of Marketing Science, 39(6), pp846-869.

McDougall, G. H., and Levesque, T. (2000). "Customer satisfaction with services: putting perceived value into the equation". Journal of Services Marketing, 14(5), pp392-410.

Melero, I., Sese, F. J., and Verhoef, P. C. (2016). "Recasting the Customer Experience in Today's omnichannel Environment 1/Redefiniendo la experiencia del cliente en el entorno omnicanal". Universia Business Review, (50), pp18.

Melis, K., Campo, K., Breugelmans, E., and Lamey, L. (2015). "The impact of the multi-channel retail mix on online store choice: Does online experience matter?" Journal of Retailing, 91(2), pp272-288.

Neslin, S. A., and Shankar, V. (2009). "Key issues in multi-channel customer management: current knowledge and future directions". Journal of Interactive Marketing, 23(1), pp70-81. 
Netemeyer, R.G., Bearden, W.O., \& Sharma, S. (2003). Scaling procedures. Issues and applications. Thousand Oaks: Sage Publications

Novak, T. P., Hoffman, D. L., and Yung, Y. F. (2000). "Measuring the customer experience in online environments: A structural modelling approach". Marketing Science, 19(1), pp22-42.

Pantano, E. and Priporas, C.V., 2016. The effect of mobile retailing on consumers' purchasing experiences: A dynamic perspective. Computers in Human Behavior, 61, pp.548-555.

Parasuraman, A., Zeithaml, V. A., and Malhotra, A. (2005). "ES-QUAL a multipleitem scale for assessing electronic service quality". Journal of Service Research, 7(3), pp213-233.

Parise, S., Guinan, P.J. and Kafka, R., 2016. Solving the crisis of immediacy: How digital technology can transform the customer experience. Business Horizons, 59(4), pp.411-420.

Park, J., and Stoel, L. (2005). "Effect of brand familiarity, experience and information on online apparel purchase". International Journal of Retail and Distribution Management, 33(2), pp148-160.

Pauwels, K., and Neslin, S. A. (2015). "Building with bricks and mortar: The revenue impact of opening physical stores in a multichannel environment". Journal of Retailing, 91(2), pp182-197.

Pauwels, K., Demirci, C., Yildirim, G., and Srinivasan, S. (2016). The impact of brand familiarity on online and offline media synergy. International Journal of Research in Marketing, 33(4), 739-753.

Picot-Coupey, K., Huré, E., and Piveteau, L. (2016). "Channel design to enrich customers' shopping experiences: Synchronizing clicks with bricks in an omnichannel perspective-the Direct Optic case". International Journal of Retail and Distribution Management, 44(3), pp336-368.

Rapp, A., Baker, T. L., Bachrach, D. G., Ogilvie, J., and Beitelspacher, L. S. (2015). "Perceived customer showrooming behavior and the effect on retail salesperson self-efficacy and performance". Journal of Retailing, 91(2), pp358-369. 
Rajamma, R.K., Paswan, A.K. and Ganesh, G., 2007. Services purchased at brick and mortar versus online stores, and shopping motivation. Journal of Services Marketing, 21(3), pp.200-212.

Raymond, J.E., Fenske, M.J. and Westoby, N. (2005). "Emotional devaluation of distracting patterns and faces: a consequence of attentional inhibition during visual search?" Journal of Experimental Psychology: Human Perception and Performance, 31(6), pp1404-1415.

Reibstein, D. J. (2002). "What attracts customers to online stores, and what keeps them coming back". Journal of the Academy of Marketing Science, 30 (4), pp465-473.

Rigby, D. (2011). "The future of shopping”. Harvard Business Review, 89(12), pp6576.

Rose, S., Hair, N., and Clark, M. (2011). "Online customer experience: a review of the business-to-consumer online purchase context". International Journal of Management Reviews, 13(1), pp24-39.

Rose, S., Clark, M., Samouel, P., and Hair, N. (2012). "Online customer experience in

e-retailing: an empirical model of antecedents and outcomes." Journal of Retailing, 88(2), pp308-322.

Roy, S., Balaji, M. S., Keshwarni, A., and Sekhon, H. (2016). "Predicting Internet banking adoption in India: A perceived risk perspective". Journal of Strategic Marketing, 25(5-6), pp418-438.

Saghiri, S., Wilding, R., Mena, C., and Bourlakis, M. (2017). Toward a threedimensional framework for omni-channel. Journal of Business Research, 77, 53-67.

Sarstedt, M., Hair, J. F., Ringle, C. M., Thiele, K. O., and Gudergan, S. P. (2016). "Estimation issues with PLS and CBSEM: Where the bias lies!". Journal of Business Research, 69(10), pp3998-4010.

Sanchez, J., Callarisa, L., Rodriguez, R. M., and Moliner, M. A. (2006). "Perceived value of the purchase of a tourism product". Tourism management, 27(3), pp394-409. 
Schlägel, C., and Sarstedt, M. (2016). "Assessing the measurement invariance of the four-dimensional cultural intelligence scale across countries: A composite model approach". European Management Journal, 34(6), pp633-649.

Sohn, S. (2017). "A contextual perspective on consumers' perceived usefulness: The case of mobile online shopping". Journal of Retailing and Consumer Services, 38, pp22-33.

Stein, A., and Ramaseshan, B. (2016). Towards the identification of customer experience touch point elements. Journal of Retailing and Consumer Services, 30, 8-19.

Steinfield, C., and Harry Bouwman, T. A. (2002). "The dynamics of click-and-mortar electronic commerce: opportunities and management strategies". International Journal of Electronic Commerce, 7(1), pp93-119.

Tseng, E. L. S., and Yazdanifard, R. (2015). "Mobility-The Revolutionary Change to Customer's Shopping Experience in Retailing". International Journal of Management, Accounting and Economics, 2(9), pp2382-2126.

Tynan, C., McKechnie, S. and Chhuon, C., 2010. Co-creating value for luxury brands. Journal of business research, 63(11), pp.1156-1163.

Verhoef, P. C., Lemon, K. N., Parasuraman, A., Roggeveen, A., Tsiros, M., and Schlesinger, L. A. (2009). "Customer experience creation: determinants, dynamics and management strategies". Journal of Retailing, 85(1), pp31-41.

Verhoef, P. C., Kannan, P. K., and Inman, J. J. (2015). "From multi-channel retailing to omnichannel retailing: introduction to the special issue on multi-channel retailing". Journal of Retailing, 91(2), pp174-181.

Verhoef, P. C., Neslin, S. A., and Vroomen, B. (2007). "Multi-channel customer management: Understanding the research-shopper phenomenon". International Journal of Research in Marketing, 24(2), pp129-148.

Wallace, D. W., Giese, J. L., and Johnson, J. L. (2004). "Customer retailer loyalty in the context of multiple channel strategies". Journal of Retailing, 80(4), pp249263.

Ye, Y., Lau, K. H., and Teo, L. K. Y. (2018). Drivers and barriers of omni-channel retailing in China: A case study of the fashion and apparel 
industry. International Journal of Retail \& Distribution Management, 46(7), 657689.

Yrjölä, M., Spence, M.T. and Saarijärvi, H., 2018. Omni-channel retailing: propositions, examples and solutions. The International Review of Retail, Distribution and Consumer Research, 28(3), pp.259-276.

Zhang, J., Farris, P. W., Irvin, J. W., Kushwaha, T., Steenburgh, T. J., and Weitz, B. A. (2010). "Crafting integrated multichannel retailing strategies". Journal of Interactive Marketing, 24(2), pp168-180.

Zhang, M., Ren, C., Wang, G. A., and He, Z. (2018). The impact of channel integration on consumer responses in omni-channel retailing: The mediating effect of consumer empowerment. Electronic Commerce Research and Applications, 28, 181-193. 


\section{Appendix 1}

\begin{tabular}{|c|c|c|}
\hline \multicolumn{2}{|c|}{ Constructs/Measures } & Item Loadings \\
\hline \multicolumn{3}{|c|}{ Brand familiarity } \\
\hline & I prefer to shop in shops I am familiar with & 0.64 \\
\hline & I like to shop in new shops that are unknown to me & 0.81 \\
\hline & I like to shop in shops that my friends or family have recommended to me & 0.7 \\
\hline & $\begin{array}{l}\text { I know that I will have a good experience when shopping in my favourite } \\
\text { shop }\end{array}$ & 0.82 \\
\hline \multicolumn{3}{|c|}{ Perceived value } \\
\hline & If using a mobile phone/tablet/computer in store: & 0.86 \\
\hline & Having free Wi-Fi is important to me & 0.87 \\
\hline & Having a fast Wi-Fi is important to me & 0.60 \\
\hline & I usually look online to compare prices before I purchase in store & 0.82 \\
\hline & It is important that the website is mobile compatible & 0.8 \\
\hline \multicolumn{3}{|c|}{ Customisation } \\
\hline & I prefer to shop with websites that remembers my details & 0.70 \\
\hline & $\begin{array}{l}\text { I can shop more easily when I am able to customise web pages to my own } \\
\text { liking }\end{array}$ & 0.67 \\
\hline & I like websites that are simple to use & 0.80 \\
\hline & I am more likely to engage with a website that: Remembers all my details & 0.75 \\
\hline \multicolumn{3}{|c|}{ Technology readiness } \\
\hline & I like to use new technologies & 0.85 \\
\hline & Technology makes me more productive & 0.8 \\
\hline & $\begin{array}{l}\text { Products and services that use the newest technologies are much more } \\
\text { convenient to use }\end{array}$ & 0.80 \\
\hline & I like to keep up-to-date with the latest technologies & 0.90 \\
\hline & Other people come to me for advice on new technologies & 0.80 \\
\hline & I can usually figure out new high-tech products without help from others & 0.79 \\
\hline & Online & \\
\hline \multicolumn{3}{|l|}{ High street } \\
\hline & Shopping on the high street is convenient & 0.69 \\
\hline & I only purchase from shops on the high street I am familiar with & 0.76 \\
\hline & Overall, I'm happy with my experience of shopping on the high street & 0.88 \\
\hline \multicolumn{3}{|c|}{ 管 } \\
\hline & $\begin{array}{l}\text { How often do you use your own mobile phone or tablet in a shop? } \\
1=\text { "not very often" and } 5=\text { "very often" }\end{array}$ & 0.87 \\
\hline & $\begin{array}{l}\text { How often have you used an information point/computer in a shop } \\
1=\text { "not very often" and } 5=\text { "very often" }\end{array}$ & 0.7 \\
\hline & $\begin{array}{l}\text { How often do you seek help and advice from a member of staff in a shop } \\
\text { (subsequently using a PC/laptop etc.)? } \\
1=\text { "not very often" and } 5 \text { = "very often" }\end{array}$ & 0.68 \\
\hline \multicolumn{3}{|c|}{ P } \\
\hline & II like to compare prices with other shops online & 0.8 \\
\hline & I like to look at online reviews of products before I purchase & 0.71 \\
\hline & I like to compare features of products online & 0.63 \\
\hline & Shopping online convenient & 0.78 \\
\hline
\end{tabular}


